\title{
Front Matter: Volume 8506
}

, "Front Matter: Volume 8506," Proc. SPIE 8506, Developments in X-Ray Tomography VIII, 850601 (13 November 2012); doi: 10.1117/12.2012093

SPIE Event: SPIE Optical Engineering + Applications, 2012, San Diego, California, SPIE. United States 


\title{
PROCEEDINGS OF SPIE
}

\section{Developments in X-Ray Tomography VIII}

\author{
Stuart R. Stock
}

Editor

13-15 August 2012

San Diego, California, United States

Sponsored and Published by

SPIE 
The papers included in this volume were part of the technical conference cited on the cover and title page. Papers were selected and subject to review by the editors and conference program committee. Some conference presentations may not be available for publication. The papers published in these proceedings reflect the work and thoughts of the authors and are published herein as submitted. The publisher is not responsible for the validity of the information or for any outcomes resulting from reliance thereon.

Please use the following format to cite material from this book:

Author(s), "Title of Paper," in Developments in X-Ray Tomography VIII, edited by Stuart R. Stock, Proceedings of SPIE Vol. 8506 (SPIE, Bellingham, WA, 2012) Article CID Number.

ISSN: 0277-786X

ISBN: 9780819492234

Published by

SPIE

P.O. Box 10, Bellingham, Washington 98227-0010 USA

Telephone +1 3606763290 (Pacific Time) · Fax +1 3606471445

SPIE.org

Copyright $@ 2012$, Society of Photo-Optical Instrumentation Engineers.

Copying of material in this book for internal or personal use, or for the internal or personal use of specific clients, beyond the fair use provisions granted by the U.S. Copyright Law is authorized by SPIE subject to payment of copying fees. The Transactional Reporting Service base fee for this volume is $\$ 18.00$ per article (or portion thereof), which should be paid directly to the Copyright Clearance Center (CCC), 222 Rosewood Drive, Danvers, MA 01923. Payment may also be made electronically through CCC Online at copyright.com. Other copying for republication, resale, advertising or promotion, or any form of systematic or multiple reproduction of any material in this book is prohibited except with permission in writing from the publisher. The CCC fee code is 0277-786X/12/\$18.00.

Printed in the United States of America.

Publication of record for individual papers is online in the SPIE Digital Library.

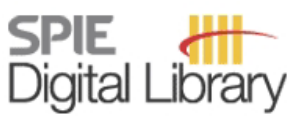

SPIEDigitalLibrary.org

Paper Numbering: Proceedings of SPIE follow an e-First publication model, with papers published first online and then in print and on CD-ROM. Papers are published as they are submitted and meet publication criteria. A unique, consistent, permanent citation identifier (CID) number is assigned to each article at the time of the first publication. Utilization of CIDs allows articles to be fully citable as soon as they are published online, and connects the same identifier to all online, print, and electronic versions of the publication. SPIE uses a six-digit CID article numbering system in which:

- The first four digits correspond to the SPIE volume number.

- The last two digits indicate publication order within the volume using a Base 36 numbering

system employing both numerals and letters. These two-number sets start with 00, 01, 02, 03, 04, 05, 06, 07, 08, 09, 0A, OB ... 0Z, followed by 10-1Z, 20-2Z, etc.

The CID Number appears on each page of the manuscript. The complete citation is used on the first page, and an abbreviated version on subsequent pages. Numbers in the index correspond to the last two digits of the six-digit CID Number. 


\title{
Contents
}

\author{
xi Conference Committee \\ xiii Introduction
}

WELCOME AND OPENING REMARKS

850602 Trends in the micro- and nanoComputed Tomography 2010-2012 [8506-1]

S. R. Stock, Northwestern Univ. (United States)

\section{SESSION 1 PHASE CONTRAST}

850603 Recent progress in four-dimensional phase tomography with grating interferometry (Invited Paper) [8506-2]

A. Momose, Tohoku Univ (Japan); S. Harasse, S. Kibayashi, M. P. Olbinado, The Univ. of Tokyo (Japan); W. Yashiro, Tohoku Univ. (Japan)

850604 Asymmetric rotational axis reconstruction of grating-based x-ray phase contrast tomography of the human cerebellum (Invited Paper) [8506-3]

G. Schulz, Univ. Basel (Switzerland); T. Weitkamp, European Synchrotron Radiation Facility (France) and Synchrotron SOLEIL (France); I. Zanette, European Synchrotron Radiation Facility (France) and Technische Univ. München (Germany); F. Pfeiffer, Technische Univ. München (Germany); M. Müller-Gerbl, Univ. Basel (Switzerland); C. David, Paul Scherrer Institut (Switzerland); B. Müller, Univ. Basel (Switzerland)

\section{SESSION 2 STUDYING DAMAGED STRUCTURES}

850607 Comparing the micro-vascular structure of cancerous and healthy tissues (Invited Paper) [8506-6]

B. Müller, S. Lang, Basel Univ. Hospital (Switzerland); F. Beckmann, Helmholtz-Zentrum Geesthacht (Germany); M. Dominietto, M. Rudin, ETH Zurich (Switzerland); I. Zanette, Technische Univ. München (Germany); T. Weitkamp, Synchrotron SOLEIL (France); A. Rack, European Synchrotron Radiation Facility (France); S. E. Hieber, Basel Univ. Hospital (Switzerland)

850609 Morphology of atherosclerotic coronary arteries [8506-8]

M. N. Holme, Basel Univ. Hospital (Switzerland) and Univ. of Fribourg (Switzerland) and Univ. Hospitals of Geneva (Switzerland); G. Schulz, H. Deyhle, S. E. Hieber, Basel Univ. Hospital (Switzerland); T. Weitkamp, Synchrotron SOLEIL (France); F. Beckmann, J. Herzen, Helmholtz-Zentrum Geesthacht (Germany); J. A. Lobrinus, Univ. Hospital of Geneva (Switzerland); F. Montecucco, F. Mach, Univ. Hospitals of Geneva (Switzerland); A. Zumbuehl, Univ. of Fribourg (Switzerland); T. Saxer, Univ. Hospitals of Geneva (Switzerland); B. Müller, Basel Univ. Hospital (Switzerland) 
8506 OA Apocalypto: revealing the unreadable [8506-9]

D. Mills, Queen Mary, Univ. of London (United Kingdom); O. Samko, P. Rosin, K. Thomas,

T. Wess, Cardiff Univ. (United Kingdom); G. R. Davis, Queen Mary Univ. of London (United Kingdom)

\section{SESSION 3 ENGINEERING APPLICATIONS}

8506 OB Development of diffraction-amalgamated grain-boundary tracking technique and its application to polycrystalline metals (Invited Paper) [8506-10]

H. Toda, D. LeClere, T. Kamiko, Toyohashi Univ. of Technology (Japan); Y. Suzuki,

A. Takeuchi, K. Uesugi, Japan Synchrotron Research Institute (Japan); M. Kobayashi, Toyohashi Univ. of Technology (Japan)

8506 OD Image-based finite element modeling of the three-point bending test of cortical bone [8506-70]

M. Binkowski, Univ. of Silesia (Poland); G. Kokot, Silesian Univ. of Technology (Poland);

F. Bolechała, Jagiellonian Univ. Medical College (Poland); A. John, Silesian Univ. of

Technology (Poland)

8506 OE Recent developments in the MuCAT microtomography facility (Invited Paper) [8506-13]

G. R. Davis, A. N. Z. Evershed, D. Mills, Queen Mary, Univ. of London (United Kingdom)

8506 OF Analysis of wood microstructure by synchrotron radiation-based x-ray microtomography (SR $\mu$ CT) [8506-12]

S. Lautner, Univ. Hamburg (Germany); F. Beckmann, Helmholtz-Zentrum Geesthacht

(Germany)

\section{SESSION $4 \quad$ IMAGING DYNAMIC SYSTEMS}

8506 0G In vivo tomographic velocimetry of the lung for the detailed study of lung disease and its treatments (Invited Paper) [8506-14]

S. Dubsky, S. B. Hooper, Monash Univ. (Australia); K. K. W. Siu, Monash Univ. (Australia) and

Australian Synchrotron (Australia); A. Fouras, Monash Univ. (Australia)

$8506 \mathrm{OH} \quad$ Mapping cardiogenic oscillations using synchrotron-based phase contrast CT imaging [8506-15]

J. Thurgood, S. Dubsky, K. K. W. Siu, M. Wallace, M. Siew, S. Hooper, A. Fouras, Monash Univ. (Australia)

8506 Ol Development of fast and high throughput tomography using CMOS image detector at SPring-8 [8506-16]

K. Uesugi, M. Hoshino, A. Takeuchi, Y. Suzuki, N. Yagi, Japan Synchrotron Radiation Research Institute (Japan)

8506 0J First small-animal in-vivo phase-contrast micro-CT scanner [8506-17] B. Pauwels, P. Bruyndonckx, X. Liu, Bruker microCT (Belgium); A. Tapfer, A. Velroyen, A. Yaroshenko, Technische Univ. München (Germany); M. Bech, Technische Univ. München (Germany) and Lund Univ. (Sweden); F. Pfeiffer, Technische Univ. München (Germany); A. Sasov, Bruker microCT (Belgium) 
8506 OK X-ray fast tomography and its applications in dynamical phenomena studies in geosciences at Advanced Photon Source (Invited Paper) [8506-18]

X. Xiao, Argonne National Lab. (United States); F. Fusseis, Ruhr-Univ. Bochum (Germany);

F. De Carlo, Argonne National Lab. (United States)

\section{SESSION $5 \quad$ POROUS SYSTEMS}

$8506 \mathrm{OL}$ Synchrotron radiation CT from the micro to nanoscale for the investigation of bone tissue (Invited Paper) [8506-19]

F. Peyrin, P. Dong, Univ. de Lyon (France) and European Synchrotron Radiation Facility (France); A. Pacureanu, Univ. de Lyon (France) and Uppsala Univ. (Sweden); M. Zuluaga, Univ. de Lyon (France); C. Olivier, M. Langer, Univ. de Lyon (France) and European Synchrotron Radiation Facility (France); P. Cloetens, European Synchrotron Radiation Facility (France)

8506 OM Combined micro computed tomography and histology study of bone augmentation and distraction osteogenesis [8506-20]

B. Ilgenstein, H. Deyhle, C. Jaquiery, C. Kunz, A. Stalder, Basel Univ. Hospital (Switzerland); S. Stübinger, Univ. of Zurich (Switzerland); G. Jundt, Basel Univ. Hospital (Switzerland); F. Beckmann, Helmholtz-Zentrum Geesthacht (Germany); B. Müller, S. E. Hieber, Basel Univ. Hospital (Switzerland)

8506 ON Comparison of propagation-based phase-contrast tomography approaches for the evaluation of dentin microstructure [8506-21]

H. Deyhle, Univ. Basel (Switzerland); T. Weitkamp, Synchrotron SOLEIL (France) and European Synchrotron Radiation Facility (France); S. Lang, G. Schulz, Univ. Basel (Switzerland); A. Rack, European Synchrotron Radiation Facility (France); I. Zanette, Synchrotron SOLEIL (France) and Technische Univ. München (Germany); B. Müller, Univ. Basel (Switzerland)

8506 OP Ground-truth verification of dynamic x-ray micro-tomography images of fluid displacement [8506-23]

G. Myers, T. Varslot, A. Kingston, The Australian National Univ. (Australia); A. Herring, Oregon State Univ (United States); A. Sheppard, The Australian National Univ. (Australia)

\section{SESSION 6 SYSTEMS I}

8506 OT An attempt to overcome diffraction limit in detectors for x-ray nanotomography [8506-27] A. Sasov, Bruker microCT (Belgium)

SESSION 7 WORK FLOW AND ANALYSIS

8506 OU tomoRecon: High-speed tomography reconstruction on workstations using multi-threading (Invited Paper) [8506-28]

M. L. Rivers, The Univ. of Chicago (United States) 
8506 OV Improving the workflow of tomography studies for the polymer additives industry [8506-29] K. Ham, Louisiana State Univ. (United States); K. White, L. S. Simeral, Albermarle Corp.

(United States); L. G. Butler, Lovisiana State Univ. (United States)

8506 0X Drishti: a volume exploration and presentation tool (Invited Paper) [8506-31]

A. Limaye, The Australian National Univ. (Australia)

\section{SESSION $8 \quad$ ALGORITHMS I}

8506 OY Prior rank, intensity and sparsity model (PRISM): a divide-and-conquer matrix decomposition model with low-rank coherence and sparse variation (Invited Paper) [8506-32]

H. Gao, Emory Univ. (United States)

$85060 Z$ An interaction based CT reconstruction algorithm for blocked projection data in a dynamic ICT system [8506-33]

M. Chang, Y. Xiao, Z. Chen, X. Jin, Tsinghua Univ. (China)

850610 An RIP-based evaluation method for candidate next generation cardiac CT architectures with carbon nanotube $x$-ray source [8506-34]

B. Liu, Wake Forest Univ. School of Medicine (United States); G. Wang, Wake Forest Univ. School of Medicine (United States) and Virginia Polytechnic Institute and State Univ. (United States); B. De Man, GE Global Research (United States); E. Krupinski, The Univ. of Arizona (United States); H. Yu, Wake Forest Univ. School of Medicine (United States)

850611 Orthogonal-rotating tetrahedral scanning for cone-beam CT [8506-35]

I. B. Ye, Virginia Polytechnic Institute and State Univ. (United States) and lowa City West High School (United States); G. Wang, Virginia Polytechnic Institute and State Univ. (United States)

850612 Multi-scale image fusion for x-ray grating-based mammography [8506-36]

$X$. Jiang, L. Zhang, Tsinghua Univ. (China); Z. Wang, Paul Scherrer Institut (Switzerland); M. Stampanoni, Paul Scherrer Institut (Switzerland) and ETH Zürich (Switzerland)

850613 A new CT architecture with stationary $x$-ray sources (Invited Paper) [8506-37]

G. Cao, Virginia Polytechnic Institute and State Univ. (United States); B. Liu, H. Yu, Wake Forest Univ. (United States); G. Wang, Virginia Polytechnic Institute and State Univ. (United States) and Wake Forest Univ. (United States)

850614 Considerations for high-magnification high-cone-angle helical micro-CT [8506-38] T. Varslot, A. Kingston, G. Myers, A. Sheppard, The Australian National Univ. (Australia)

850615 Calibration of a combined laboratory microCT/microXRF system [8506-39]

X. Liu, P. Bruyndonckx, A. Sasov, Bruker microCT (Belgium) 
850616 Energy-resolved Compton scatter estimation for micro-CT [8506-40]

A. M. T. Opie, Univ. of Canterbury (New Zealand); A. P. H. Butler, Univ. of Canterbury (New Zealand) and Univ. of Otago (New Zealand); P. J. Bones, Univ. of Canterbury (New Zealand)

850617 High-resolution and high-speed CT in industry and research [8506-41]

S. Zabler, Julius-Maximilians-Univ. Würzburg (Germany) and Fraunhofer-Institut für Integrierte Schaltungen (Germany); C. Fella, Julius-Maximilians-Univ. Würzburg (Germany); A. Dietrich, F. Nachtrab, M. Salamon, V. Voland, Fraunhofer-Institut für Integrierte Schaltungen (Germany); T. Ebensperger, Julius-Maximilians-Univ. Würzburg (Germany) and FraunhoferInstitut für Integrierte Schaltungen (Germany); S. Oeckl, Fraunhofer-Institut für Integrierte Schaltungen (Germany); R. Hanke, Julius-Maximilians-Univ. Würzburg (Germany) and Fraunhofer-Institut für Integrierte Schaltungen (Germany); N. UhImann, Fraunhofer-Institut für Integrierte Schaltungen (Germany)

\section{SESSION 10 SYSTEMS III}

850618 X-ray micro-tomography at the Advanced Light Source [8506-42]

A. A. MacDowell, D. Y. Parkinson, A. Haboub, E. Schaible, J. R. Nasiatka, C. A. Yee, J. R. Jameson, J. B. Ajo-Franklin, Lawrence Berkeley National Lab. (United States); C. R. Brodersen, Univ of Florida (United States); A. J. McElrone, Univ. of California, Davis (United States)

\section{SESSION $11 \quad$ ALGORITHMS II}

8506 1B High order total variation method for interior tomography (Invited Paper) [8506-46] J. Yang, Peking Univ. (China); H. Yu, Virginia Polytechnic Insitute and State Univ (United States) and Wake Forest Univ. School of Medicine (United States); W. Cong, Virginia Polytechnic Institute and State Univ. (United States); M. Jiang, Peking Univ. (China) and Virginia Polytechnic Institute and State Univ. (United States); G. Wang, Virginia Polytechnic Institute and State Univ. (United States) and Wake Forest Univ. School of Medicine (United States)

8506 1C Anisotropic total variation minimization method for limited-angle CT reconstruction [8506-47]

X. Jin, L. Li, Z. Chen, L. Zhang, Y. Xing, Tsinghua Univ. (China)

8506 ID X-ray beam hardening correction by minimizing reprojection distance [8506-48] A. M. Kingston, G. R. Myers, T. K. Varslot, The Australian National Univ. (Australia)

8506 IE Improved total variation based CT reconstruction algorithm with noise estimation [8506-49] X. Jin, L. Li, L. Shen, Z. Chen, Tsinghua Univ. (China) 
8506 IG Macro- and microstructural diversity of sea urchin teeth revealed by large-scale mircro-computed tomography survey [8506-51]

A. Ziegler, Harvard Univ. (United States); S. R. Stock, Northwestern Univ. (United States);

B. H. Menze, ETH Zurich (Switzerland); A. B. Smith, The Natural History Museum (United Kingdom)

$8506 \mathrm{lH}$ Investigating biofilm structure using x-ray microtomography and gratings-based phase contrast [8506-52]

E. A. Miller, Pacific Northwest National Lab. (United States); X. Xiao, Argonne National Lab. (United States); M. Miller, P. Keller, T. A. White, M. Marshall, Pacific Northwest National Lab. (United States)

850611 Application of a novel diffraction-based tomography method for imaging biological samples [8506-53]

C. R. Samarage, G. J. Sheard, A. Fouras, Monash Univ. (Australia)

POSTER SESSION

$85061 \mathrm{~K}$ Self-calibration for a multi-segment straight-line trajectory CT using invariant moment [8506-55]

X. Li, Z. Chen, X. Jiang, Y. Xing, Tsinghua Univ. (China)

8506 1L A geometrical correction method for radioactive intensity image reconstruction in tomographic gamma scanning [8506-56]

Z. Liu, L. Zhang, X. Jiang, Tsinghua Univ. (China)

8506 1M A noise variance estimation approach for CT [8506-57]

L. Shen, X. Jin, Y. Xing, Tsinghua Univ. (China)

8506 iN Multi-species beam hardening calibration device for x-ray microtomography [8506-58]

A. N. Z. Evershed, D. Mills, G. Davis, Queen Mary, Univ. of London (United Kingdom)

850610 An iterative reconstruction method for high-pitch helical luggage CT [8506-59] H. Xue, L. Zhang, Z. Chen, X. Jin, Tsinghua Univ. (China)

8506 IP Fast imaging method for grating-based $x$-ray computed tomography [8506-60] Y. Xi, J. Zhao, Shanghai Jiao Tong Univ. (China)

$85061 Q \quad$ Imaging properties of circular and helical interlaced source-detector CT [8506-61] Y. Chen, Y. Xi, J. Zhao, Shanghai Jiao Tong Univ. (China)

8506 IR Evaluation of oral scanning in comparison to impression using three-dimensional registration [8506-62]

Y.-C. Brogle-Kim, H. Deyhle, B. Müller, G. Schulz, Basel Univ. Hospital (Switzerland);

T. Bormann, Basel Univ. Hospital (Switzerland) and Univ. of Applied Sciences Northwestern Switzerland (Switzerland); F. Beckmann, Helmholtz-Zentrum Geesthacht (Germany);

K. Jäger, Basel Univ. Hospital (Switzerland) 
8506 is Comparison of denture models by means of micro computed tomography [8506-63] C. Vögtlin, G. Schulz, H. Deyhle, K. Jäger, Univ. Basel (Switzerland); T. Liebrich, S. Weikert, ETH Zurich (Switzerland); B. Müller, Univ. Basel (Switzerland)

8506 IV Unified dual-modality image reconstruction with dual dictionaries [8506-66]

Y. Lu, J. Zhao, T. Zhuang, Shanghai Jiao Tong Univ. (China); G. Wang, Virginia Polytechnic Institute and State Univ. (United States)

8506 IW Radiation dose performance in the triple-source CT based on a Monte Carlo method [8506-67]

Z. Yang, J. Zhao, Shanghai Jiao Tong Univ. (China)

8506 1X Stereo-imaging towards spectrography for 3D analysis from a single spectral view [8506-68]

Y. Xi, Shanghai Jiao Tong Univ. (China); G. Wang, Virginia Polytechnic Institute and State Univ. (United States); H. Yu, Wake Forest Univ. School of Medicine (United States); Y. Wang, Argonne National Lab. (United States); J. Zhao, Shanghai Jiao Tong Univ. (China)

8506 1Y Spectrography: volumetric reconstruction from one or two spectral views [8506-69] H. Yu, Wake Forest Univ. School of Medicine (United States); G. Wang, Wake Forest Univ. School of Medicine (United States) and Virginia Polytechnic Institute and State Univ. (United States)

Author Index 
Proc. of SPIE Vol. 8506 850601-10

Downloaded From: https://www.spiedigitallibrary.org/conference-proceedings-of-spie on 26 Apr 2023 Terms of Use: https://www.spiedigitallibrary.org/terms-of-use 


\section{Conference Committee}

Program Track Chair

Carolyn A. MacDonald, University at Albany (United States)

Conference Chair

Stuart R. Stock, Northwestern University (United States)

Conference Program Committee

Felix Beckmann, Helmholtz-Zentrum Geesthacht (Germany)

Graham R. Davis, Queen Mary, University of London (United Kingdom)

Atsushi Momose, The University of Tokyo (Japan)

Bert Müller, Universität Basel (Switzerland)

Andrew G. Peele, Australian Synchrotron (Australia) and La Trobe University (Australia)

Erik Leo Ritman, Mayo Clinic (United States)

Mark L. Rivers, The University of Chicago (United States)

Ge Wang, Virginia Polytechnic Institute and State University (United States)

Session Chairs

1 Phase Contrast

Stuart R. Stock, Northwestern University (United States)

2 Studying Damaged Structures

Erik Leo Ritman, Mayo Clinic (United States)

3 Engineering Applications

Atsushi Momose, The University of Tokyo (Japan)

$4 \quad$ Imaging Dynamic Systems

Mark L. Rivers, The University of Chicago (United States)

5 Porous Systems

Erik Leo Ritman, Mayo Clinic (United States)

6 Systems I

Mark L. Rivers, The University of Chicago (United States) 
7 Work Flow and Analysis

Graham R. Davis, Queen Mary, University of London (United Kingdom)

8 Algorithms I

Ge Wang, Virginia Polytechnic Institute and State University (United States)

9 Systems II

Bert Müller, Universität Basel (Switzerland)

10 Systems III

Felix Beckmann, Helmholtz-Zentrum Geesthacht (Germany)

11 Algorithms II

Atsushi Momose, The University of Tokyo (Japan)

12 Water, Water Everywhere

Stuart R. Stock, Northwestern University (United States) 


\section{Introduction}

The field of x-ray tomography, with emphasis on micro- and nano-scale 3D imaging, continues to develop rapidly. Many more laboratory and storage-ringbased Computed Tomography (CT) systems are in operation, churning out data sets, than there were in August 2010 when the last Developments conference was held. Spectral CT is one example of a rapidly developing modality.

A clear indication that a field (e.g. tomography by all techniques) has reached critical mass is when graduate and post-doctoral fellows band together in a selfhelp society. At Northwestern University, for example, Tomographers Annonymous has met monthly for over one year and acts, independently of faculty, as a center of analysis expertise, advice, and brainstorming (http://www.tomographers.northwestern.edu/). Perhaps eventually, there will be an international tomography society. With many more than $10^{3}$ papers on $x$-ray microCT published annually, there is certainly the activity level to warrant such an organization. Further, the third generation of tomographers is coming into their own (e.g., students of students of faculty such as Prof. Ulrich Bonse who established this conference).

The eighth conference in the Developments series filled three entire days (oral presentations) and an evening poster session. There was a stimulating balance between mathematical treatment of reconstructions and of artifact reduction on the one hand, and experimental studies and instrumentation development on the other.

The diversity of applications underlined the mature interdisciplinary scope of the conference. Established groups continued the trend of more detailed and sophisticated analyses than in previous meetings, and new contributors (both early career and senior investigators) brought fresh ideas to the meeting.

I would like to thank the authors for their excellent talks and papers, invited and contributed; over 50 manuscripts from 68 presentations appear in the conference volume. I also thank the program committee for their very important help. Last, but not least, the SPIE staff provided exemplary support with the program development, the meeting itself, and the proceedings.

Stuart R. Stock 
Proc. of SPIE Vol. 8506 850601-14

Downloaded From: https://www.spiedigitallibrary.org/conference-proceedings-of-spie on 26 Apr 2023 Terms of Use: https://www.spiedigitallibrary.org/terms-of-use 